\title{
沿岸漂砂量, 波による地形変化の限界水深およ び波候特性の関係 \\ RELATIONS AMONG WAVE CLIMATE, LONGSHORE SAND TRANSPORT RATE AND CLOSURE DEPTH
}

\author{
宇多高明 ${ }^{1} \cdot$ 芹沢真澄 $^{2} \cdot$ 熊田貴之 ${ }^{3} \cdot{\text { 加留部亮太 }{ }^{4} \cdot \text { 三浦正寛 }}^{5}$ \\ Takaaki UDA, Masumi SERIZAWA, Takayuki KUMADA, Ryota KARUBE and Masahiro MIURA \\ 1正会員 工博 国土技術政策総合研究所研究総務官 (テ305-0804茨城県つくば市旭1) \\ ${ }^{2}$ 正会員 海岸研究室(有) ( $1160-0011$ 東京都新宿区若葉1-22 ローヤル若葉208号) \\ 3学生会員 工修 日本大学大学院理工学研究科海洋建築工学専攻 (厂274-8501 船橋市習志野台7-24-1) \\ ${ }^{4}$ 日本大学大学院理工学研究科海洋建築工学専攻 (同上) \\ ${ }^{5}$ 日本大学理工学部海洋建築工学科 (同上)
}

\begin{abstract}
Relations among the wave climate, longshore sand transport rate and the closure depth were investigated based on longshore sand transport rate and the closure depth measured at many coasts in Japan, and wave data measured by NOWPHAS. A relationship $h_{c}=3.64 H_{95}$ was derived by the regression analysis, where $h_{c}$ is the closure depth and $H_{95}$ is the wave height of $95 \%$ probability of occurrence. Absolute value of longshore sand transport rate was expressed by $|Q|=1.97 \times 10^{4} \mathrm{H}_{95}{ }^{5 / 2}$.
\end{abstract}

Key Words : wave climate, closure depth, longshore sand transport rate, NOWPHAS

\section{1. まえがき}

我が国沿岸では海岸保全などを目的とした深浅測量が 過去数十年にわたり行われるとともに, 波浪観測網の積 極的な展開によって海浜変形やそれを引き起こす外力で ある波浪データがかなり高い密度で集積されてきた.こ れらのうち海浜変形など漂砂関連のデータについて筆者 の一人は全国データの集積および分析を行い, 例えば波 の作用下で有意な地形変化が見られなくなる限界の水深 （波による地形変化の限界水深）や沿岸漂砂量などの全 国実態を明らかにした1).このように海浜変形に関する 現地データの集積はかなり進んできたが, それらと波浪 データとの突き合わせ分析はなお不十分であり, 波浪 データからこれらの值の推定法については十分明らかで ないのが現状である.このことから, 本研究は,この点を 明らかにすることを主な目的とする.

海浜変形特性を全国レベルで眺める場合に必要となる 波浪条件は, 海域の波浪特性を代表するという意味から 波候特性として整理されたものが望ましい.この種の データとして全国を網羅し,かつ観測期間が十分長いも
のに旧運輸省による波浪観測網で測定されたNOWPHAS波 浪データがある. 本研究ではこのデータを用いると同時 に, 宇多1 に集約されている, 波による地形変化の限界 水深や漂砂の移動高, さらには沿岸漂砂量と波浪デー夕 との関係を調べ, 波候特性からこれらの值を推算する方 法について検討する.

波による地形変化の限界水深は, 各種漂砂制御施設の 設計においてそれらの先端水深を定める上で有効な判断 材料となるが, その值を求めるには海浜維断形の比較を 行う必要があることから,一般に少なくとも過去数年間 にわたって集積された深浅測量データが必要である.し かし海浜維断形が経年的に測量されていない場所で各種 構造物の設計を行わなければならない場合には, 別の方 法による限界水深の推定法が必要となる.これには, 底質 中央粒径 $\left(d_{50}\right)$ の水深分布において, 汀線付近での粗な 粒径が水深の増加とともに減少し, 波による地形変化の 限界水深付近では $0.2 \mathrm{~mm}$ 程度で水深によらず一定となる ことを利用する手法と, 波候特性から推定する方法など が考えられるが,これらを経験的手法に基づいて提案す ることが本研究の目的である. 


\section{2. 沿岸漂砂量等の全国実態}

\section{（1）沿岸漂砂量の全国実態}

宇多 ${ }^{1)}$ は, 全国57海岸と4湖岸の地形変化を実態デー タに基づいて検討し, 各海（湖）岸の沿岸漂砂量を算出 した(文献1)の表6.1.1，p.415). 沿岸漂砂量の算定が可 能な海岸数は29, 湖岸は3, 合計で32であった. なお波の遮 蔽構造物が伸ばされたためその背後域で土砂が堆積する 場合防波堤が大きく伸びた直後に沿岸漂砂量は大きく, 時間経過とともに沿岸漂砂量は減少するから, 文献中の 表6.1.1では観測期間中で最も大きな沿岸漂砂が観測さ れた時期を選んでいる.一方, 既往の研究2) ー6)による沿岸 漂砂については, 5海岸での沿岸漂砂量の算定が行われて いる(文献1)の表6. 1. 3, p. 417参照) .

具体的な漂砂量については省略するが, 一般的に外 海・外洋に面した海岸での沿岸漂砂量は $10^{5} \mathrm{~m}^{3} / \mathrm{yr}$ のオー ダーである. しかし, 富津岬, 石巻湾, 鈴鹿川河口部など半 島などにより波が遮蔽されている海岸での沿岸漂砂量で は $10^{4} \mathrm{~m}^{3} / \mathrm{yr}$ のオーダーとなる. また御座海岸など著しく

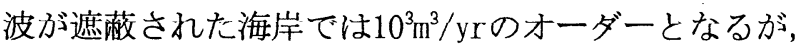
この沿岸漂砂量は規模の大きな湖である琵琶湖での值と 同じオーダーである.さらに規模の小さな湖では $10^{2} \mathrm{~m}^{3} / \mathrm{yr}$ の沿岸漂砂量を有している.

\section{（2）波による地形変化の限界水深の全国実態}

波の作用による底質の移動限界の算定では, 従来から 移動限界水深が広く使われてきている. 移動限界水深は, 底質の比重, 中央粒径, 波高 - 周期に依存する.いま底質 の比重と中央粒径が一定としても, 現地海岸の波浪は不 規則波であるために波高・周期は大きく変動し，した がって移動限界水深はこれらの波浪条件に依存して変化 することになる. しかしながら例えば漂砂移動を阻止す るための突堤や防波堤の先端水深の設計などにおいては, ある期間（数年以上と比較的長い期間）を通じて平均的 に見たとき,工学的に有意な地形変化が見られなくなる 限界の水深が必要となる. そこで, 本研究ではこの水樑の ことを波による地形変化の限界水深 $\left(h_{c}\right)$ と定義す る. $h_{c}$ は, 繰り返し行われた深浅測量データをもとにした 海浜縦断形比較から定めることができる. 宇多 ${ }^{1)}$ の表 6.2.1 (p. 418)には $h_{c}$ の一覧を示す. また表6.2.2(p. 418) には, 既往の研究2), 6) 10) で求められている $h_{c}$ も示してあ る.詳細なデータについてここでは論じないが，一般に外 海・外洋に面した海岸における $h_{c}$ は10m程度であり, 内海 では2〜 3m, さらに湖では1m程度となる.
旧運輸省の波浪観測網で測定されたNOWPHAS波浪デー タでは, 図-1に示すように全国40地点での波浪データか ら有義波高について0〜2.0mでは0.25m間隔で, $2.0 〜 7.0 \mathrm{~m}$ では0.5m間隔で, さらに7.0m以上の波高では1.0m間隔で 波浪の出現回数が示されている. そこで,このデータをも とに未超過確率がそれぞれ50, 80, 90, 95, 98\%に相当する 有義波高を整理した. 相対的に高波高を選んだのは，海浜 変形が, 出現頻度は高いがエネルギーレベルの低い波高 よりも，出現頻度はそれほど高くないがエネルギーレベ ルの高い波浪により主として支配されていると考えたた めである.

$h_{c}$ が求められた地点のうち近傍に上述の波浪観測点が 存在する場合を取り出すと表-1となる. 全体では14地点 となる. 表-1には, 対応する波浪観測地点の 5 種類の未超 過確率波高を示すとともに, 波浪データの統計期間も示 す. 波浪統計期間は平均で約12年である.一方, 選定され た $h_{c}$ は 3 15mのレンジを有している.

図一には $h_{c}$ の算出地点を示す.また表-1をもとに, $h_{c}$ と末超過確率波高の関倸を調べた. まず, 図-3(a)〜図$3(\mathrm{e})$ には $h_{c}$ と5種類の未超過確率波高の関係を示す.また, 表一には相関係数をまとめてある.それぞれの相関図を 見ると, 未超過確率 $50 \%$ 波高では相関が明らかに低いが, 未超過確率が増大するにしたがい相関保数は次第に上昇 し,未超過確率 $90 \%$ ないし $95 \%$ 波高において相関係数は 最大の0.81 となる.一般に, 出現頻度の非常に低い高波浪 になれば久測の可能性が高くなって統計データの信頼性 も低下寸ること，また未超過確率 $98 \%$ 波高と $95 \%$ 波高と で同様に高い相関係数が得られたことから,ここでは未 超過確率 $95 \%$ 波高 $\left(H_{95}\right)$ を代表として選ぶことにする. この場合 $h_{c}$ は相関係数 0.81 で次式により表される.

$$
h_{c}=3.64 H_{95}
$$

このように $h_{c}$ が未超過確率 $95 \%$ というかなり出現頻度の 低い波高と高い相関を有し, 未超過確率 $50 \%$ 波高などの ように出現頻度の高い波高との相関が低いことは注目さ れる.なぜなら, ある期間（数年以上と比較的長い期間） を通じて平均的に見たとき, 工学的に有意な地形変化が 見られなくなる限界の水深と定義した $h_{c} か ゙$, 通常時の波 浪ではなく高波浪時の波によって強く支配されているこ とを示しているからである.

\section{（2） $h_{c}$ と沿岸漂砂量の関係}

宇多 ${ }^{1)}$ は, 全国の海岸での実測データをもとに, $h_{c}$ と沿 岸漂砂量の絶対值 $|Q|$ に関して次式の関係が成立する ことを示した.

\section{3. 各変数間の相互関係}

$$
|Q|=780 h_{c}^{5 / 2}
$$

\section{（1）波浪データと $h_{c}$ の関係}




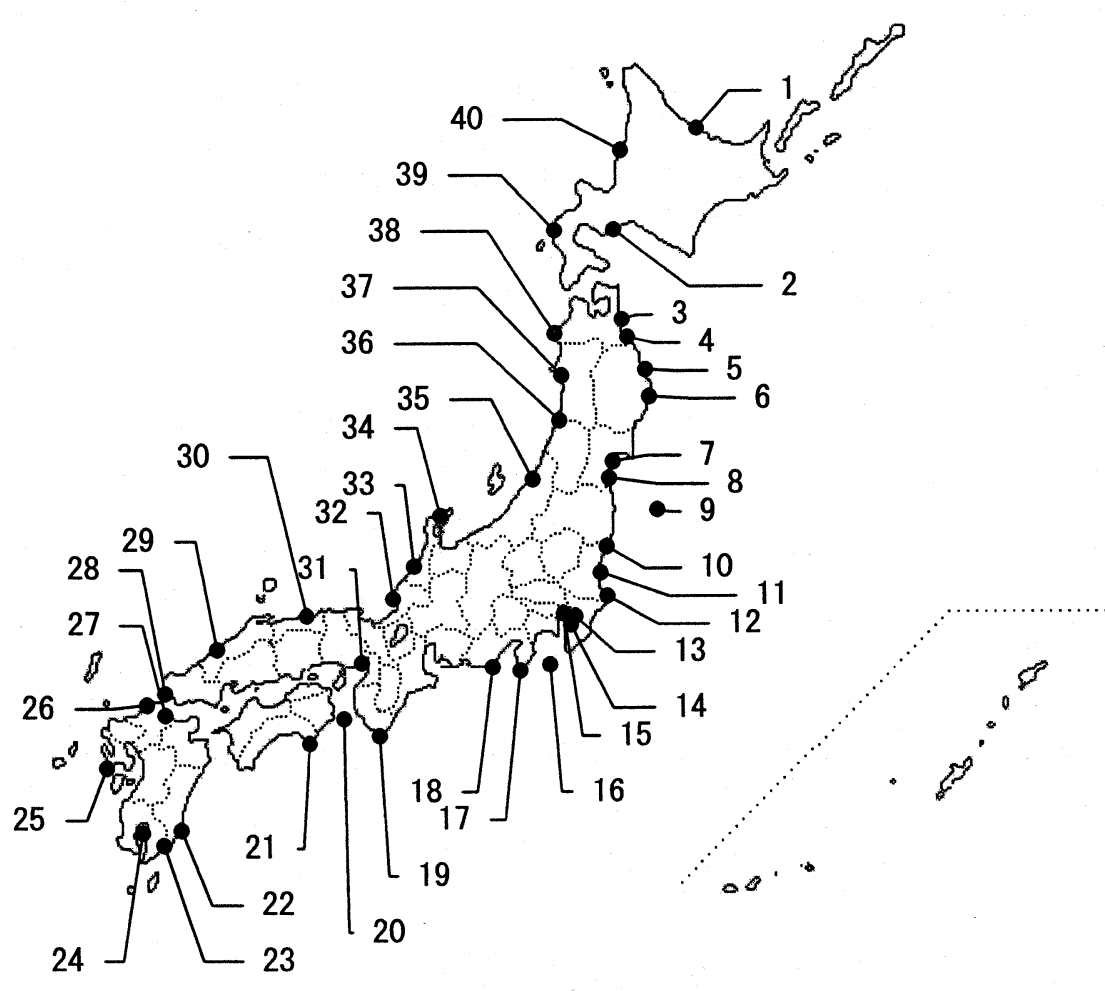

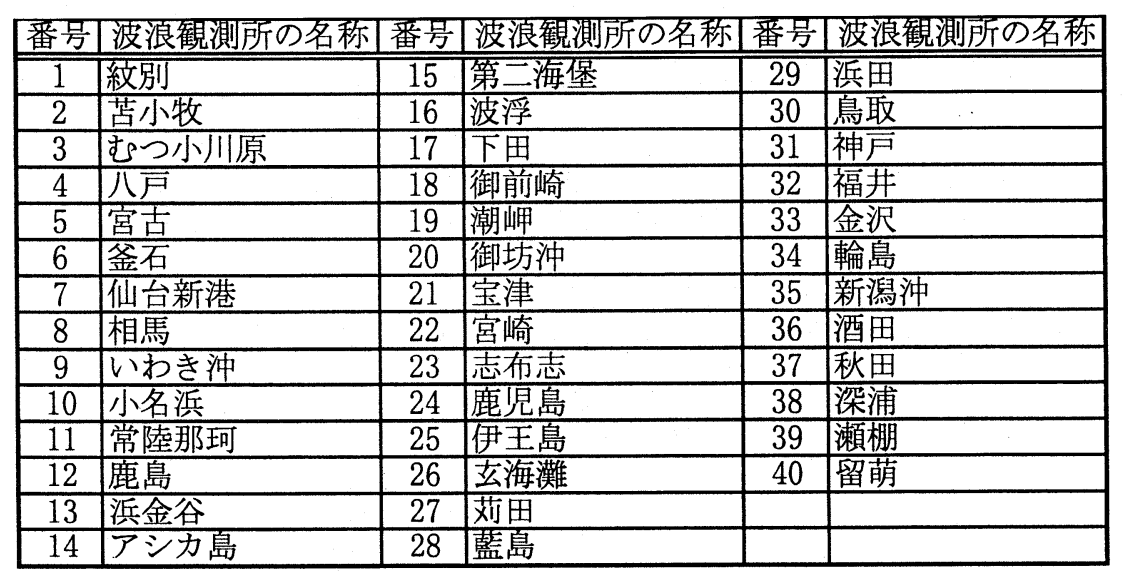

図-1 全国の波浪観測所

表-1 NOWPHAS波浪データによる未超過確率波高, 波による地形変化の限界水深, 漂砂の移動高の一覧

\begin{tabular}{|c|c|c|c|c|c|c|c|c|c|}
\hline \multirow{2}{*}{ 波浪観測所 } & \multirow{2}{*}{ 統計年月 } & \multicolumn{5}{|c|}{ 波高 } & \multirow{2}{*}{$\begin{array}{c}\begin{array}{c}\text { 限界水深 } \\
(\mathrm{m})\end{array} \\
\end{array}$} & \multirow{2}{*}{$\begin{array}{c}\text { 漂砂の移動高 } \\
(\mathrm{m})\end{array}$} & \multirow{2}{*}{ 海岸名称 } \\
\hline & & $50 \%$ & $80 \%$ & $90 \%$ & $95 \%$ & $98 \%$ & & & \\
\hline 苫小牧 & 13力年 & 0.64 & 1.08 & 1.45 & 1.83 & 2.38 & 6 & 6.7 & 北海道日高海岸 \\
\hline むつ小川原 & 21力年 & 0.89 & 1.48 & 1.96 & 2.47 & 3.19 & 8 & 11 & 青森県三沢海岸 \\
\hline 仙台新港 & 16力年 & 0.71 & 1.11 & 1.41 & 1.71 & 2.19 & 8 & 6.1 & 宮城県石巻湾沿岸 \\
\hline いわき沖 & 4力年 & 1.47 & 2.18 & 2.70 & 3.26 & 4.13 & 9 & 11 & 福島県北部～宮城県南部沿岸 \\
\hline 相馬 & 13力年 & 0.88 & 1.33 & 1.66 & 1.98 & 2.48 & 8 & - & 宮城県仙台湾沿岸 \\
\hline 深浦 & 15力年 & 0.85 & 1.95 & 2.71 & 3.38 & 4.20 & 14 & - & 秋田県能代沿岸 \\
\hline 酒田 & 22力年 & 0.91 & 1.97 & 2.73 & 3.40 & 4.27 & 15 & - & 山形県沿岸 \\
\hline 鹿島 & 11力年 & 1.18 & 1.83 & 2.31 & 2.77 & 3.38 & 8 & 6.1 & 茨城県鹿島灘浻岸 \\
\hline 第二海堡 & 4力年 & 0.37 & 0.47 & 0.56 & 0.68 & 0.76 & 3 & 4 & 千葉県富津岬 \\
\hline 新潟沖 & 6力年 & 0.71 & 1.62 & 2.28 & 2.87 & 3.56 & 8 & - & 新潟県新潟沿岸 \\
\hline 御前崎 & 7力年 & 0.68 & 1.12 & 1.46 & 1.80 & 2.31 & 3 & - & 静岡県相良片浜海岸 \\
\hline 潮岬 & 8力年 & 0.95 & 1.54 & 2.03 & 2.49 & 3.20 & 10 & - & 三重県七里御浜海岸 \\
\hline 鳥取 & 16力年 & 0.88 & 1.77 & 2.40 & 2.91 & 3.49 & 14 & - & 鳥取県鳥取海岸 \\
\hline 宮崎 & 5力年 & 0.97 & 1.64 & 2.22 & 2.75 & 3.49 & 10 & 15 & 宮崎県宮崎海岸 \\
\hline
\end{tabular}




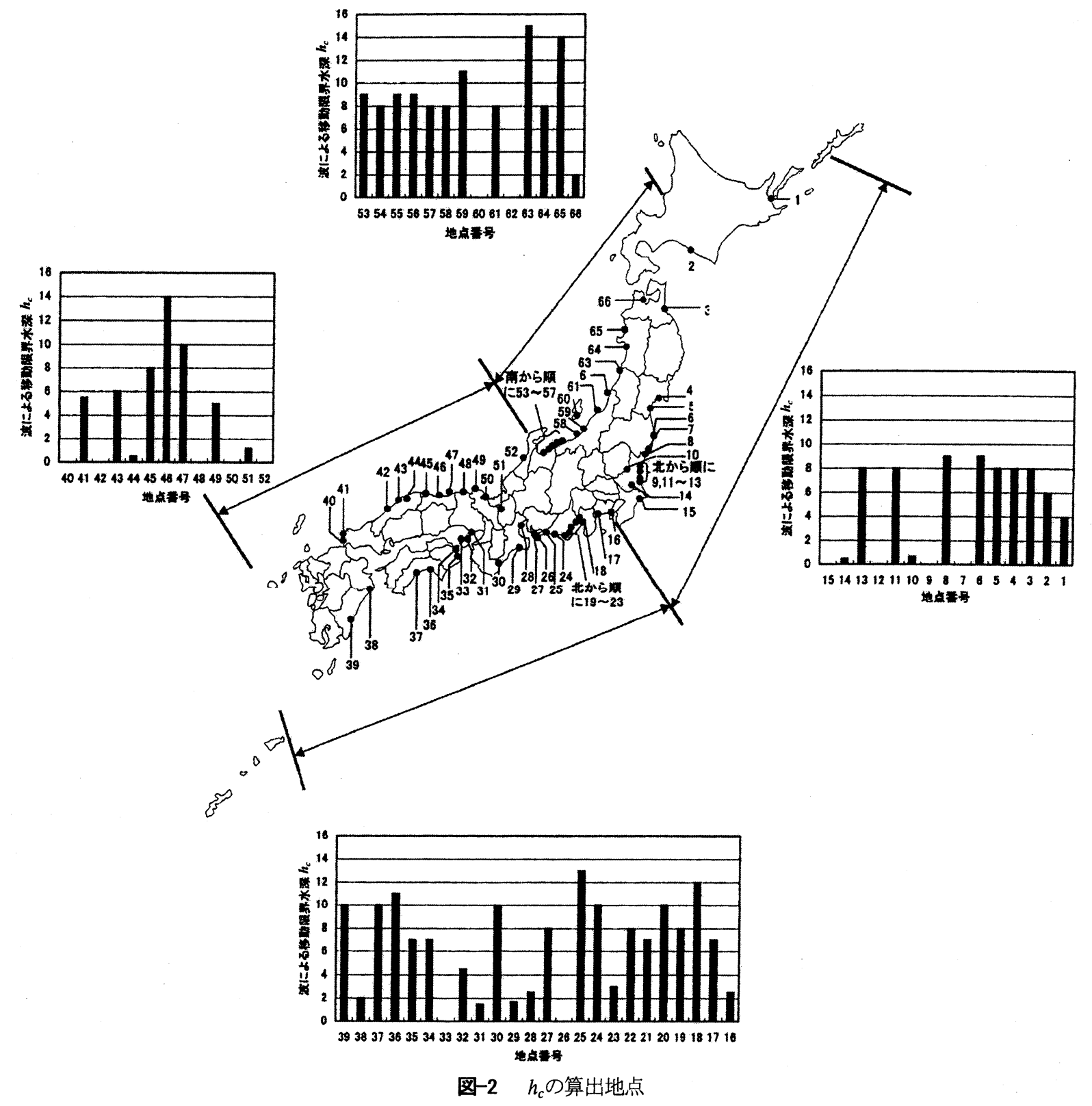

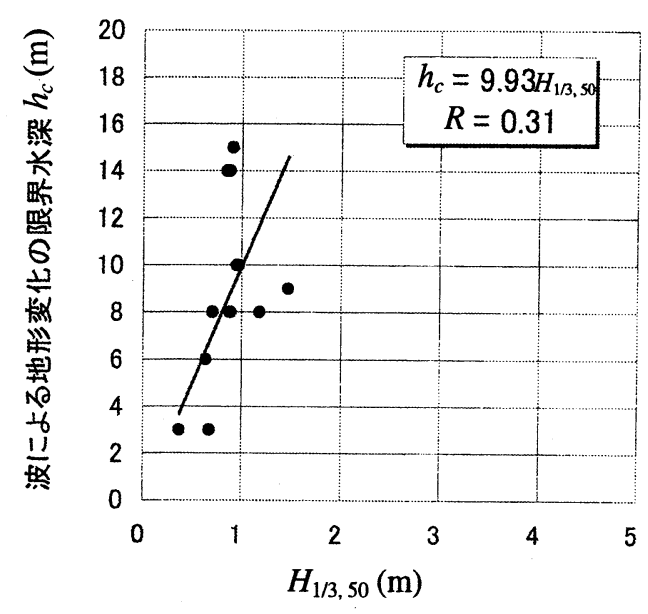

图-3（a） $h_{c}$ と末超過確率50\%波高の関係

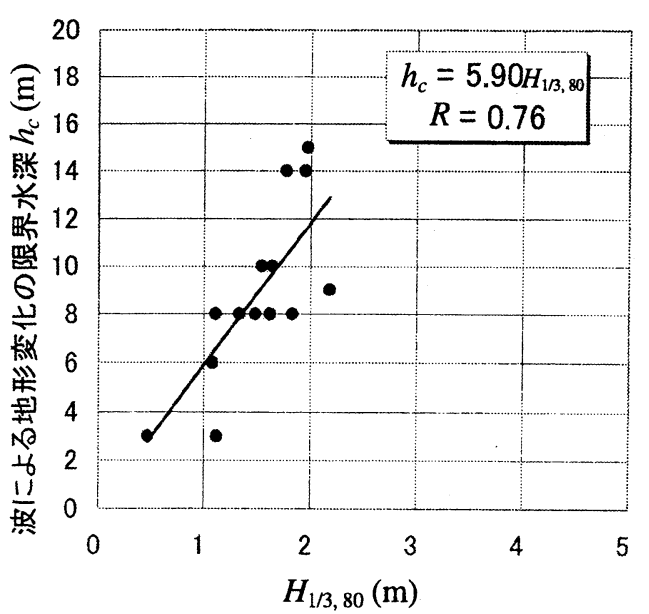

図-3(b) $h_{c}$ と末超過確率 $80 \%$ 波高の関係 


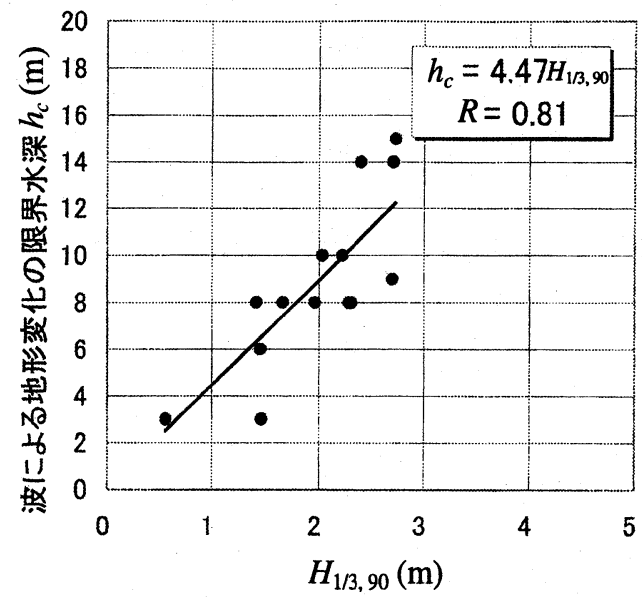

図-3(c) $h_{c}$ と末超過確率 $90 \%$ 波高の関係

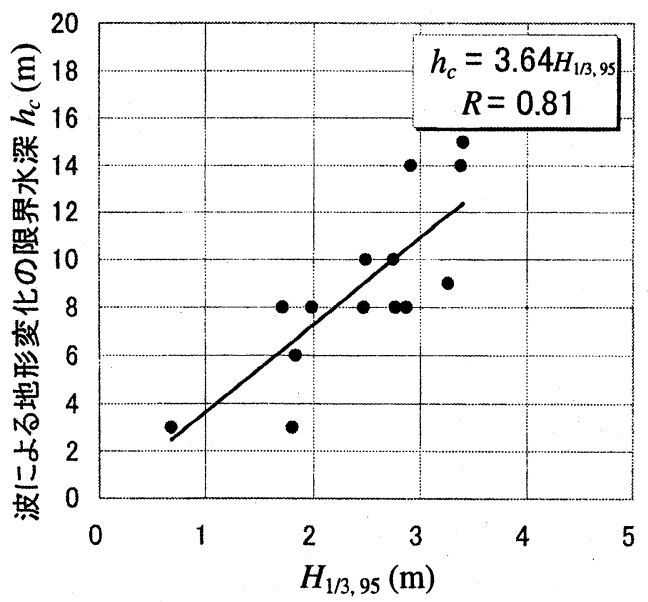

図-3 (d) $h_{c}$ と末超過確率 $95 \%$ 波高の関係

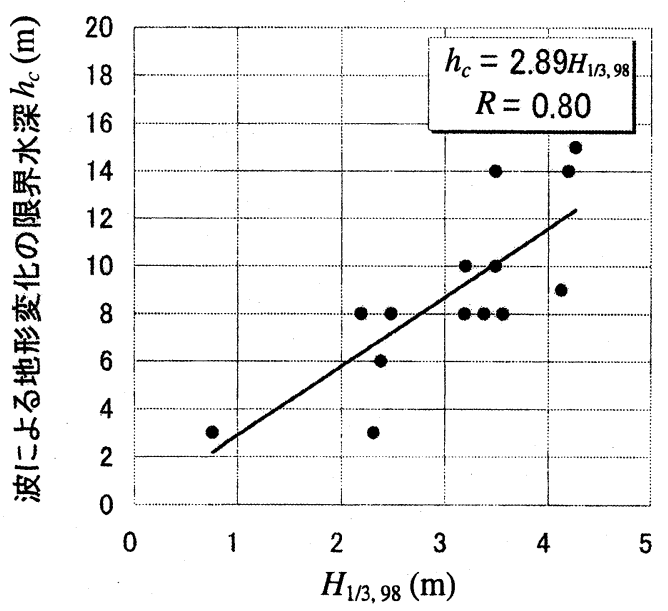

図-3(e) $h_{c}$ と末超過確率 $98 \%$ 波高の関係

このことは, 波による地形変化の限界水深の大きい場所 では, 限界水深の $5 / 2$ 乗に比例して沿岸漂砂量が増大する ことを意味している.したがって, ある地点での波による 地形変化の限界水深が推定されれば, これから沿岸漂砂 量のオーダーの推定が可能となる. 本研究によれば, $h_{c}$ と 未超過確率 $95 \%$ 波高 $H_{95}$ の間には式 (1) が成立するので, この関係を式 (2) へ代入すると,
表-2 相関係数の一覧

\begin{tabular}{|c|c|c|c|}
\hline 項目 & 波高未超過確率 & 相関係数 $(R)$ & 回㷌式 \\
\hline \multirow{3}{*}{ 限界 } & $50 \%$ 波高 & 0.31 & $h_{c}=9.93 H_{1 / 3,50}$ \\
\cline { 2 - 4 } 水深 & $80 \%$ 波高 & 0.76 & $h_{c}=5.90 H_{1 / 3,80}$ \\
\cline { 2 - 4 }$h_{c}(\mathrm{~m})$ & $90 \%$ 波高 & 0.81 & $h_{c}=4.47 H_{1 / 3,90}$ \\
\cline { 2 - 4 } & $95 \%$ 波高 & 0.81 & $h_{c}=3.64 H_{1 / 3,95}$ \\
\cline { 2 - 4 } & $98 \%$ 波高 & 0.80 & $h_{c}=2.89 H_{1 / 3,98}$ \\
\hline
\end{tabular}

$$
|Q|=1.97 \times 10^{4} H_{95}^{5 / 2}
$$

となる. 沿岸漂砂量のオーダーは, 未超過確率 $95 \%$ 波高の 5/2乗に比例する量として与えられる.

\section{4. 現地海岸における沿岸漂砂量の推定手法}

宇多ら ${ }^{13)}$ は底質中央粒径 $\left(d_{50}\right)$ の水深方向分布を調心， 海底谷に続くような急勾配海岸を除けば, $d_{50}$ は汀線付近 での粗な值から水深方向に減少し，ある水深を境に水深 によらずほぼ一定で, 0.15 0. $2 \mathrm{~mm}$ 程度の一様粒径に変化 することを現地データから示すとともに, この限界水深 を粒径変化の限界水深と定義し,この值と波による地形 変化の限界水深との関係を調べた. この結果, 粒径変化の 限界水深は, 波による地形変化の限界水深とほぼ一対一 対応を示すことが明らかになった.この結果は，過去に繰 り返し行われた深浅測量データがなくても，ある時期に 行った底質採取より $d_{50}$ の水深方向分布を求めれば, 水深 方向の $d_{50}$ の変化から $h_{c}$ の推定が可能なことを示している. この手法自体かなり有効であるが, これに加えて, 本研究 の結果では, 調查対象海岸の周辺に波浪観測所があり, そ れより波浪統計データが利用可能であれば, 未超過確率 95\%波高データに基づいて波による地形変化の限界水深 の推定が可能となる.

さらに $h_{c}$ とその地点における沿岸漂砂量の絶対値の関 係も示されていることは, 例えば等深線変化モデルなど の数值モデルの適用において, 仮に長期間にわたって取 得された深浅測量データがなかったとしても, $h_{c}$ や沿岸 漂砂量の最大值などが予め評価されうることから, 海浜 変形の予測計算を合理的に進める上で重要な結果が得ら れたと考えられる. また, $d_{50}$ の水深方向分布の測定が行 われておれば, それらのデータと組み合わせることに よって, 全体の推定精度の向上につながると考えられる.

また, $d_{50}$ の水深分布は, ある測線上で観測船を高精度 で走行させて求めたものではなく,任意の平面位置にお いて, 底質採取を行った測定点の水深さえ明らになって いれば分布形が描けることから, 波による地形変化の限 界水深算定のための簡易手法として利用可能である.こ の方法によれば多少推定精度は低くても, 経年的な深浅 測量を行わずとも波による地形変化の限界水深の推定が 可能となる. 


\section{5. まとめ}

（1）旧運輸省のNOWPHAS波浪観測データと, $h_{c}$ の関係を 調べた結果, 未超過確率 $95 \%$ 波高 $\left(H_{95}\right)$ を用いると相関 係数0. 81 で $h_{c}=3.64 H_{95}$ なる関係が得られた.

(2) また, 既往の研究で得られている $h_{c}$ と沿岸漂砂量の 絶対值 $|Q|$ に関する $|Q|=780 h_{c}^{5 n}$ の関係に (1) で 示された関係を代入した結果, $|Q|=1.97 \times 10^{4} H_{95}{ }^{5 / 2}$ なる関係式が得られた.

\section{参考文献}

1）宇多高明：日本の海岸侵食, 山海堂, p. 442, 1997.

2）三村信男・加藤 始 : 大洗海岸における近年の地形 変化と沿岸漂砂量, 第34回海岸工学講演会論文 集, pp. 362-366, 1987.

3）土屋義人・芝野照夫：下新川海岸の海浜過程につい て, 第20回海岸工学講演会論文集, pp. 483-488, 1973.

4）橋本 宏: 海浜変形モデルの富士海岸への応用, 第23 回海岸工学講演会論文集, pp. 218-220, 1976.

5）井島武士・佐藤昭二・早瀬幸一：伊良湖港の漂砂に ついて, 第5 回海岸工学講演会講演集, pp. 97106, 1958.

6）矢島道夫 $\cdot$ 上薗 晃 - 矢内常夫 $\cdot 山$ 田文雄 : 天橋立
におけるサンドバイパス工法の適用, 第29回海岸工学 講演会論文集, pp. 304-308, 1982.

7）尾崎 晃：日高静内海岸の海浜過程について, 第21回 海岸工学講演会論文集, pp. 135-139, 1974.

8）佐藤昭二・河西輝夫 - 田中則男 - 入江 功：小川原 湖海岸の漂砂について, 第19回海岸工学講演会論文 集, pp. 7-11, 1972.

9）松富英夫・工藤 修・池田正人：秋田県南部海岸で の漂砂動向, 海岸工学論文集, 第 39 巻, pp. 341345, 1992.

10）三村信男 - 加藤 始 - 永井紀彦・堀井昭宏 : 常陸那 珂海岸における海岸地形変化の特性, 海岸工学論文 集, 第37巻, pp. 354-358, 1990.

11）合田良実・佐藤昭二 : 海岸・港湾, 土木学会編, 彰国 社, p. 396, 1972.

12）運輸省港湾局：全国港湾海洋波浪観測25力年統計資 料（NOWPHAS1970～1994）（財）沿岸開発技術研究 センター, 1996.

13）宇多高明 - 小菅 晋・芹沢真澄 - 三波俊郎 - 古池 鋼 : $d_{50}$ の水深分布から波による地形変化の限界水 媣を推定する方法, 海岸工学論文集, 第 44 巻, pp. 521-525, 1997. 